\section{Invited Synthesis Paper}

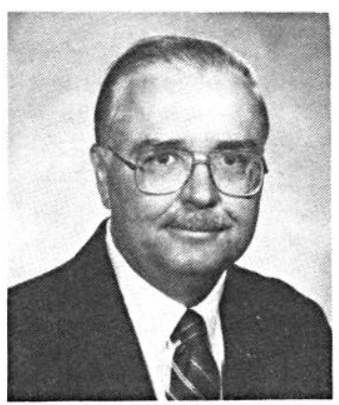

NEIL E. WEST has offered his overview of how the issues of biodiversity may influence planning, research, and management of rangelands.

Neil grew up on a cattle and sheep ranch in southern Oregon. He went to Oregon State University with the intention of becoming a chemist. His career was irrevocably changed, however, when he learned, in an introductory zoology class, about the outdoor orientation of the then esoteric science of ecology. He attained a B.S. in general science and continued directly into a Ph.D. program in plant ecology at OSU. His doctoral work focused on the effects of fire exclusion on ponderosa pine forests in central Oregon. After a short assignment at the
Oregon Forest Research Lab in Corvallis, West decided to relocate to the drier terrain of Utah. West has been at Utah State University, Logan, most of the time since 1964. L.A. Stoddart and C.W. Cook were important early mentors. He has tried to overcome his western biases by spending a semester or more at the University of Georgia; Yale University; Adelaide University, South Australia; and Hebrew University, Jerusalem, Israel.

West has chosen the difficult and often unappreciated professional task of attempting to keep up with the output of theoretical synecologists and translating the applicable portions to the improvement of rangeland management. His current efforts focus on the scientific underpinnings of sustainability, desertification, monitoring of trend and interpretation of rangeland condition. Unless his wife Alexa can dissuade him otherwise, Neil is usually to be found each weekend sampling the aquatic and upland ecosystems of the Intermountain regions behind a gun or fishing rod.

\title{
Biodiversity of rangelands
}

\author{
NEIL E. WEST
}

Author is professor, Range Science Department; Utah State University, Logan 84322-5230.

\begin{abstract}
Biodiversity is a multifaceted phenomenon involving the variety of organisms present, the genetic differences among them, and the communities, ecosystems, and landscape patterns in which they occur. Society will increasingly value biodiversity and influence the passage of laws and writing of regulations involving biodiversity which rangeland managers will have to abide by over the coming decades. Even private and developing world rangelands will be affected.

While taxonomic knowledge of vertebrates and vascular plants and their abundance, rarity, and distribution, in the developed nations is generally adequate, the same cannot be said of the developing world. Furthermore, adequate knowledge of invertebrates, nonvascular plants, and microbes is deficient everywhere.

Although the basis of variation at all higher levels, genetic variation within rangeland species, even the major ones, has barely been assessed. Obtaining statistically adequate data on populations of rare species that are small and secretive is well nigh impossible.

We have many means of measuring community diversity, but all of them are value laden. That is, choice of variables to measure and how they are indexed betrays what we consider are important. We should be more forthright in stating to the users the biases of these methods. There are many other, more useful ways to describe community-level diversity besides the tradtional focus on species.
\end{abstract}

Manuscript accepted 5 Sept. 1992
Ungulate grazing is an important process in many ecosystems. Thus, removal of grazing destabilizes some systems. Livestock grazing will actually increase the chances of survival of some species. Moderate livestock grazing can also enhance community and landscape-level diversity in many instances.

Attention is now shifting from "charismatic" species to defensively managing larger tracts of land with habitat or ecosystems holding suites of sensitive species. Since some accelerated extinction of isolated populations and species is inevitable, we need to know which species and ecotypes are most valuable. Understanding of modular, guild, and functional group structure would also help us identify keystone or critical link species and better focus our attention on truly important tracts of land where they live.

It is probably more important to sustain soils and ecosystem processes than any randomly selected species, especially if functionally redundant species can be identified. Similarly, not all introduced, alien, or exotic species are equal threats; it depends on how they fit into ecosystems. Sustainable development will depend on finding balance between use and protection, from range sites to landscapes, and even on a global basis.

Key Words: extinction, invasion, keystone species, functional groups, guilds, critical link species, sustainability, fragmentation, National Forest Management Act, Surface Mining Control and Reclamation Act 
The threat of global environmental change, accelerated species extinctions, and changing societal values has caused biodiversity to become a topic that has captured the attention of the public as well as the scientific community (Anon. 1991a). Laws regulating biodiversity have been passed and more legislation is being proposed. Even if no new laws are passed, it appears that further expansion of regulations and enforcement will have considerable effects on how rangelands will be managed in coming decades. Although the alteration of management because of concerns for biodiversity will occur first on federal lands in the western U.S., the management of private rangelands will also probably be increasingly influenced by regulations involving biodiversity. Indeed, even the style of assistance in developing nations is being changed by concerns for biodiversity from the World Bank and the governments of donor or assisting nations (McNeely et al. 1989). Thus, all those concerned with rangeland management worldwide will eventually become influenced by this issue. We can either wait for the influences to become evident and react after regulations are in place or we can become proactive. If rangeland management professionals are to have any input to the writing of laws and regulations or redirection of monitoring and research programs, they must understand what biodiversity is, why it is valued, and how its monitoring and regulation will influence future rangeland policies and management practices.

\section{Biodiversity Defined}

The broadest concept of diversity is that of variety. Although environmental variety includes physical, chemical, topographic, edaphic (soils), and meteorological (climatic) factors, mankind is usually most interested in the variety of other organisms. In simplest terms, biological diversity (hereafter shortened to biodiversity), is the variety of life and its processes, including the variety of living organisms, the genetic differences among them, the communities, ecosystems, and landscapes in which they occur, plus the interactions of these components (Fig. 1). Some (Salwasser 1991, GomezPompa and Kaus 1992) would add the local peoples, their culture, and their "indigenous knowledge" to the list of what should be retained. The definition used here is considerably broader than that used historically by biogeographers, community, and evolutionary ecologists. Magurran (1988) recently observed that “Diver- sity is rather like an optical illusion, the more it is looked at, the less clearly defined it appears to be and viewing it from different angles can lead to different perceptions of what is involved." Peters (1991) further warns that biodiversity should not be viewed as a single phenomenon, but as a "concept cluster". Stability and sustainability are also related concept clusters; thus if these notions are combined with biodiversity, particularly complex issues arise.

\section{Genetic Diversity}

Each plant, animal, and microbial species occurring on rangelands has variation in its DNA-based genetic structure over space and time. Genetic diversity found within species is the ultimate source of biodiversity at higher levels, determining how species interact with their environments and each other. Generally, the shorter the life span and the greater the role of sexual reproduction, the greater the genetic variation, although other features such as mating systems (Pimm 1991) may influence these traits. While range scientists have long recognized the importance of empirically identifying ecotypes of important plants used in planting efforts, the genetic reasons for these differences are only beginning to be investigated. Durant McArthur's work with sagebrushes (Artemisia spp.) and Douglas Dewey's work with wheatgrasses and ryegrasses (Triticeae tribe of grasses) are notable exceptions. Less conspicuous and less economically important species have rarely had their genetic structure considered. Fortunately, new techniques are becoming available to accelerate this type of work in the future.

\section{Species Populations}

As mankind has gained increasing power to change the biosphere, there is little doubt that rates of extinction have begun to greatly exceed rates of evolution of new species (Ehrlich and Wilson 1991). Because of the inertia of various human tendencies now in place, loss of many more species is inevitable (Holdgate 1991). The majority of the world's species are naturally rare (Williams 1964), many being relicts from former times with different environments. About half of the world's species, mostly insects, occur in the tropics. The reputation of the world's drylands as having low biodiversity is, however, false (Cody 1989, Pimm and Gittleman 1992).

Disturbance tends to favor those organisms with broad ecologi-

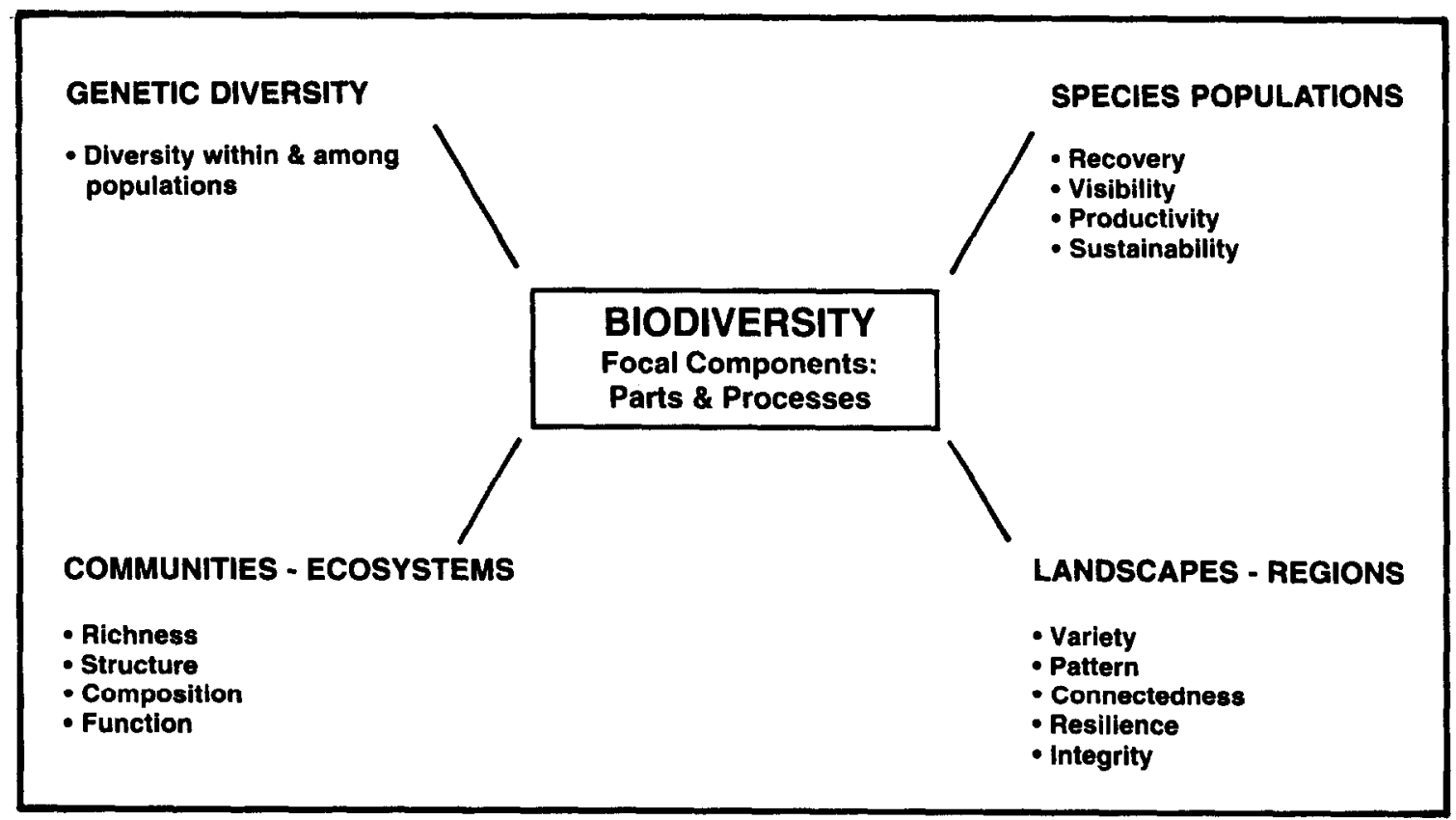

Fig. 1. Components of biodiversity. From Anon 1991b. Reprinted with permission of the Keystone Center. 
cal tolerances and shorter life cycles. Because agriculture has historically favored cultivation of short-lived species with rapid growth rates, "weedy" species (both plant and animal) have increased in proportionate abundance over the nonweedy ones. Moreover, as the proportion of the earth that was wildland has diminished, we have observed the loss of species requiring the more stable conditions of nondeveloped areas. The cosmopolitization of the world's fauna and flora in disturbed habitats is viewed as "biological pollution" to some (Howarth 1983).

\section{Communities}

Associations or assemblages of species make up communities. Any management action or inaction (failure to actively manage) involves a trade-off between species that benefit from subsequent changes and those that do not. Consequently, species occurrences and their relative abundances can be altered due to management actions, such as changes in livestock grazing and/or fire regimes. Although the data have rarely been evaluated in ways to bring out the impacts of various management systems on community diversity, there are a myriad of techniques to collect and synthesize such data at the community level (Magurran 1988). These will be discussed later.

\section{Ecosystems}

An ecosystem is the biological community in an area plus the physical environment with which it interacts. The variety of species, growth forms, life cycles, and phenological and physiological modes (e.g., $\mathrm{C}_{3}, \mathrm{C}_{4}, \mathrm{CAM}$ plants) present in a community qualitatively and quantitatively influence the environment and processes operative at the ecosystem level. For instance, whether leguminous or nonleguminous or otherwise $\mathrm{N}$-fixing shrubs are allowed to prosper in savannas has a profound influence on the spatial variability in micro-climate, water budgets, nitrogen fixation, and animals present and their plane of nutrition.

\section{Landscapes and Regions}

Biodiversity is also patterned at the scales of hillslopes, watersheds, and landscapes. Romme and Knight (1982) suggest that changes in landscape pattern may influence a variety of other natural features including animal use, water, and nutrient cycles, and even the probability of different kinds of natural disturbances. Kinds of ecosystems, their level of various functions (e.g., productivity, nutrient cycling) and linkages (e.g., water, sediment) are being increasingly scrutinized as advanced remote sensing, geographic information systems, computerized image interpretation, and multivariate statistical techniques allow data to be organized across broad scales (Pickup 1989). These tools are also allowing a new consideration of regional patterns of diversity now becoming known as epsilon diversity (Burton et al. 1992). Gap analysis (Scott et al. $1987,1988,1989$ ) is attempting to recognize where discontinuities occur in protection, largely between the national reserve and refuge system.

\section{Importance of Scale}

It should now be obvious that biodiversity can be considered at a variety of scales in both space and time. Whether a short-term change in local species richness can lead to a significant long-term change in overall biodiversity is a question of temporal and geographic scales. If the organisms that are harmed by a given management action are already rare or more imperiled than ones that benefit, or if the manipulation eliminates a local population or a species throughout its range, a community, or an ecosystem process, then biodiversity is reduced. If the manipulation eliminates an element that is common elsewhere in the landscape or provides an opportunity for an imperiled element in the landscape to migrate or increase, then biodiversity is more secure. It is thus obvious that we have to consider the impacts of any project at place and times well beyond the point of action. Because benefits are typically economic, immediate, and known, while costs are ecological, long term, and unknown, it is very difficult to objectively balance costs and benefits (Solbrig 1992).

The fundamental problem with more tightly defining biodiversity is that different people favor looking at different phenomena at much different scales in space and time (Table 1). The "diversity" of scientists, technicians, users and other interested parties with different value systems involved in such a vast array of features is bound to create difficulties in reaching consensus on what to measure and how to measure it. Thus, the only reliable means of knowing what people really mean when they use the term biodiversity is to ask what and how they would measure. Their answers must clearly spell out which levels of integration and temporal and spatial scales they favor. Furthermore, without a tightly stated purpose for estimating diversity, we cannot decide on the most relevant measure(s) of biodiversity. Failure to make objectives explicit insures continued frustration because what constitutes ecological good remains as much as matter of human opinion as it is a subject of science.

One must be aware that patterns and processes at 1 spatial or temporal scale affect those at other scales. For instance, diminishment of migratory small birds, largely because of loss of tropical winter habitat, may eventually influence ecosystem structure at higher latitudes because of changed seed predation, seed dissemination, pollination, etc., which could lead to changing vegetation structure. Greater diversity at 1 spatial scale need not translate to greater diversity at another scale (Hoover and Parker 1991). Monitoring a suite of phenomena simultaneously at several scales becomes prohibitively expensive. Thus, we must learn how to relate the various features and levels to each other and then match the combinations with the most efficient monitoring approaches.

\section{Why Biodiversity Is Important}

Changes in biodiversity, by whatever measure used, should be of concern to everyone for at least 1 of 4 basic reasons. The first reason involves morality. Many believe that humans have a moral obligation to protect their fellow creatures, whether any extrinsic value is placed on them or not. The relative strength of this feeling depends on one's own philosophical and religious orientation, namely mankind's place in nature. The second reason involves aesthetics. The human desire to see and appreciate the living parts of nature and add interest, value, and quality to their lives is reflected in the popularity of wildlife films, visits to zoos, botanical gardens, and ecotourism. The third reason involves economics. In addition to the economic spin-offs of the aesthetic values (e.g., ecotourism), there are many direct benefits to humans from biodiversity in the form of "goods" such as foods, medicines, fuel, building materials, and industrial products. Crops and domestic animals are "borrowed" from the "genetic library" of nature (Ehrlich and Wilson 1991). The potential of that "library" has scarcely been tapped. Some of these potential uses will be forever lost by allowing extinction to accelerate.

The fourth, least understood, but most important value of biodiversity is the array of "services" provided by natural ecosystems (Westman 1977, Walker 1992). Essential ecosystem services include maintenance of the gaseous composition of the atmosphere; amelioration of climates; genesis, fertility, and stability of soils; disposal of wastes; cycling of nutrients; natural control of pathogenic and parasitic organisms, etc. Loss of biodiversity can negatively influence both the quality and quantity of ecosystem services and ultimately have economic consequences. Although it is logical to expect that reducing the biological variability of a system reduces its resilience and increases the probability that rare events which formerly could be "absorbed" will cause dramatic change and 
Table 1. Indicator variables for inventorying, monitoring, and assessing terrestrial biodiversity at 4 levels of organization, including compositional, structural and functional components, inventory and monjtoring tools and techniques (from Noss 1990). Reprinted with permission of the Society for Conservation Biology and Blackwell Scientific Publications, Inc.

\begin{tabular}{|c|c|c|c|}
\hline \multirow[b]{2}{*}{ Levels of } & \multirow[b]{2}{*}{ Composition } & \multicolumn{2}{|c|}{ Classes of Indicators } \\
\hline & & Structure & Function \\
\hline $\begin{array}{l}\text { Regional } \\
\text { Landscape }\end{array}$ & $\begin{array}{l}\text { Identify, distribution richness } \\
\text { and proportions of patch } \\
\text { (habitat) types and multi- } \\
\text { patch landscape type; } \\
\text { collection patterns of species } \\
\text { distributions (richness, } \\
\text { endemism) }\end{array}$ & $\begin{array}{l}\text { Heterogeneity; connectivity; } \\
\text { spatial linkage; patchiness; } \\
\text { porosity; contrast, grain } \\
\text { size; fragmentation; } \\
\text { configuration; } \\
\text { juxtaposition; patch size } \\
\text { frequency distribution; } \\
\text { perimeter-area ratio; } \\
\text { pattern of habitat layer } \\
\text { distribution }\end{array}$ & $\begin{array}{l}\text { Disturbance processes (areal } \\
\text { extent, frequency or return } \\
\text { interval, rotation period, } \\
\text { predictability, intensity, } \\
\text { severity, seasonality); } \\
\text { nutrient cycling rates; } \\
\text { energy flow rates; patch } \\
\text { persistence and turnover } \\
\text { rates; rates of erosion and } \\
\text { geomorphic and hydrologic } \\
\text { processes; human land-use } \\
\text { trends }\end{array}$ \\
\hline
\end{tabular}

Inventory and monitoring
tools

Aerial photographs

(satellite and

conventional aircraft)

and other remote sensing

data; Geographic

information Systems

(GIS) technology; time

series analyses; spatial

statistics; mathematical

indices (of pattern,

heterogeneity,

connectivity, layering

diversity, edge,

morphology,

autocorrelation, fractal

dimension)

\author{
Substrate and soil \\ variables; slope and aspect; \\ vegetation biomass and \\ physiognomy; foliage density \\ and layering; horizontal \\ patchiness; canopy openness \\ and gap proportions: \\ abundance, density and \\ distribution of key physical \\ features (e.g., cliffs, \\ outcrops, sinks) and \\ structural elements (snags, \\ down logs): water and \\ resource (e.g. mast \\ availability; snow cover
}

\author{
Biomass and resource \\ productivity, herbivory, \\ parasitism, and predation \\ rates, colonization and \\ local extinction rates; \\ patch dynamics (fine-scale \\ disturbance processes), \\ nutrient cycling rates: \\ human intrusion rates and \\ intensities \\ Aerial photographs and \\ other remote sensing \\ data; ground-level photo \\ stations; time series \\ analysis; physical \\ habitat measures and \\ resource inventories: \\ habitat suitability \\ indices (HSI, \\ multispecies); \\ observations, censuses \\ and inventories, \\ captures, and other \\ sampling methodologies; \\ mathematical indices \\ (e.g. of diversity, \\ heterogeneity, layering \\ dispersion, biotic \\ integrity)
} \begin{tabular}{ll}
\hline $\begin{array}{l}\text { Species } \\
\text { Population }\end{array}$ & $\begin{array}{l}\text { Absolute or relative abundance; } \\
\text { frequency; importance or cover } \\
\text { values; biomass, density }\end{array}$
\end{tabular}

\section{Dispersion}

(Microdistribution); range (macrodistribution); population structure (sex ratio, age ratio); habitat variables (see communityecosystem structure, above); within-individual morphological variability

\author{
Demographic processes \\ (fertility, recruitment \\ rate, survivorship. \\ mortality); metapopulation \\ dynamics; population \\ genetics (see below); \\ population fluctuations; \\ physiology; life history; \\ phenology; growth rate (of \\ individuals); accumulation; \\ adaptation
}

Censuses (observations, counts, captures, signs, radio-marking); remote sensing; habitat suitability index (HSI) species habitat modeling; population viability analysis

$\begin{array}{ll}\text { Inbreeding depression; } & \text { Electrophoresis; } \\ \text { outbreeding rate: rate of } & \text { karyotypic analysis; DNA } \\ \text { genetic drift; gene flow; } & \text { sequencing; offspring- } \\ \text { mutation rate; selection } & \text { parent regression; sib } \\ \text { intensity } & \text { analysis; morphological } \\ & \text { analysis }\end{array}$

injure the system (Archer and Smeins 1991), the science so far brought to bear on this topic has not been strong (Peters 1991, Solbrig 1992, Walker 1992, Johnson and Mayeux 1992, Allen and Hoesktra 1992).

\section{Measurement of Diversity at the Community Level}

Methods for assessing biodiversity vary among hierarchial levels of organization (Table 1). Some basic concepts and principles of measurement are similar, however. Because community level aspects of measuring biodiversity are of greatest inherent interest to range professionals and have had the longest history of development, methodological focus herein will be for assessing biodiversity at the community level of organization. Some of these techniques can also be employed at landscape levels (Turner et al. 
1990, Burton et al. 1992).

Community biodiversity, also sometimes known as intra-stand or alpha biodiversity, deals with the numbers of taxa and their relative abundances within a stand (an area of sufficient homogeneity with regard to vegetation, soils, topography, micro-climate, and past disturbance history to be treated as a single unit). The usual compound expressions of community biodiversity really involve 2 fundamental features: (1) richness, also sometimes known as variety or species density; and (2) relative abundances of component taxa, also called equitability or evenness. Most of the suggested indices of community level biodiversity (over 90 proposed indices have been published, but an infinite number of indices are possible [Ludwig and Reynolds 1988]) involve both richness and equitability, often in ill-defined ways.

\section{Richness}

Because increasing number of taxa are usually encountered as the cumulative area sampled increases (species-area curve, Fig. 2), any small sample will usually underestimate the maximum richness

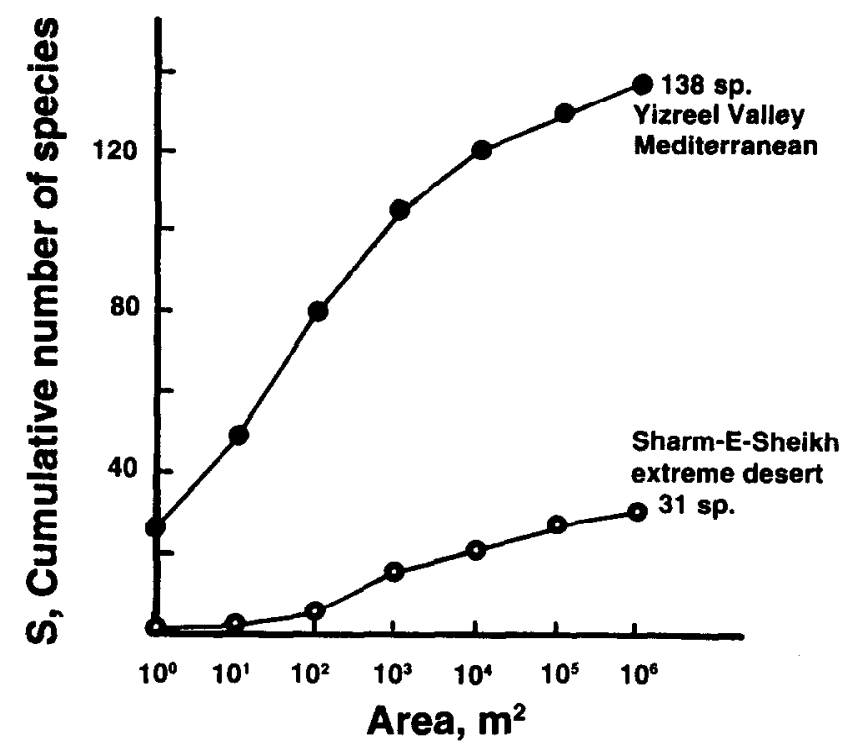

Fig. 2. Species-area curves for Yizreel Valley and Sharm-E-Sheikh regions of Israel (Shmida and Wilson 1985). Reprinted with permission of Blackwell Scientific Publications, Ltd.

possible within a stand. When a sample is used to estimate stand richness, it is assumed some predictable relationship exists between the actual number of taxa sampled (s) and the real total number of taxa $(S)$ present. It is often assumed that $s$ is directly proportional to the logarithm of area (a) sampled. If true, one could theoretically extrapolate from any size sample to an entire area about which one choses to generalize. Unfortunately, no single equation has been found to be valid in all circumstances, and all empirically derived curves have been nonlinear. Furthermore, in certain instances, species richness has been found to not increase as size of area sampled increased (Boeklen and Gotelli 1984, Dunn and Loehle 1988). The rate at which species richness increases, or not, with area is related to the combined effects of 4 biological determinants: niche relations, habitat diversity, mass effects, and ecological equivalency (Shmida and Wilson 1985).

Richness is affected also by evenness, spatial pattern (patchiness), and natural disturbances or human-induced treatments. Thus, adjusting plot size and shape and increasing plot numbers to compare different stands may not yield statistically valid results (Christensen and Peet 1984, Palmer 1990). All we currently know is that, given equally rich communities, numbers of taxa will usually increase toward an asymptote (levelling off of the curve) most rapidly in those communities in which the constituent taxa are most equally abundant, small in size, and randomly intermingled in space. As community equitability decreases, organism size increases (due to human treatments or natural causes), or taxa become spatially segregated, more samples are required to observe a particular portion of the total taxa potentially present.

\section{Equitability}

Relative abundance or evenness of taxa is frequently viewed as more important to land resource managers than richness. For instance, rangeland managers often prefer an abundance of only a few highly palatable plant species when their goals center on livestock production. Thus, they, do not want to treat all plant species equally in a diversity index.

Several metrics of equitability have been developed from heterogeneity (richness combined with equitability) measures by standardizing against the maximum possible value. The major difficulty with these metrics is that they require knowing the actual number of species ( $S$ ) present in the sampling universe. Because $S$ is usually underestimated from subsampling (Palmer 1990), equitability is usually overestimated. Obviously, variations in sample size, as well as random variations in $s$, or the distributions of abundances among species affect these measures (Peet 1974). Under most circumstances, it is best to avoid trying to express equitability by itself (Christensen and Peet 1984). Where species presence is nearly equivalent, however, it is useful to graphically tease out differences in equitability over either time or space to show how communities change in terms of relative abundances of species and growth forms (e.g., Lewis et al. 1988, Yorks et al. 1992).

\section{Heterogeneity}

Most ecologists have preferred to combine richness and equitability into a single measure known as heterogeneity (Peet 1974). Heterogeneity can be equated with the uncertainty that exists regarding the taxonomic or other group membership of an individual selected at random from a community (Pielou 1966). The uncertainty of membership increases with either increased richness or decreased equitability. Because information content is a measure of uncertainty, information theory-based indices are often used to express heterogeneity (Ludwig and Reynolds 1988).

Simpson (1949) first proposed that heterogeneity is inversely related to the probability that 2 individuals selected at random from a community will belong to the same species. Routledge's $(1979,1984)$ modification of Simpson's index of concentration can be used at several hierarchial levels within and beyond stands. Estimates of variance and tests of statistical significance can be done with computer-intensive methods (Hatton and West 1987).

Information theory-based heterogeneity indices are more sensitive to changes in rare species than the probability theory-based indices (e.g., Simpson's and its modifications), which are more sensitive to changes in common species. The appropriate use of these indices thus varies depending upon whether one wants to stress the total biota or the more abundant taxa within the community. It should be realized, however, that information of usually greatest interest to a manager becomes submerged from view by such data compressions into an index number (which can be arrived at an infinite number of ways).

Cardinal measures (Cousins 1991) such as richness treat all taxa equally. All of the information theory-derived indices (Williams alpha, Shannon's H and J, as well as others, see Hill 1973) are cardinal indices.

Ordinal measures, which treat each taxon differently and express their ranking in a particular order, are more ecologically sound (Walker 1992) and offer advantages for environmental assessment (Cousins 1991). Relative statistical abundance distributions (such as log-normal, Fig. 3) are not the only ordinal tool we have for analyzing diversity, but ordering by size and functional 


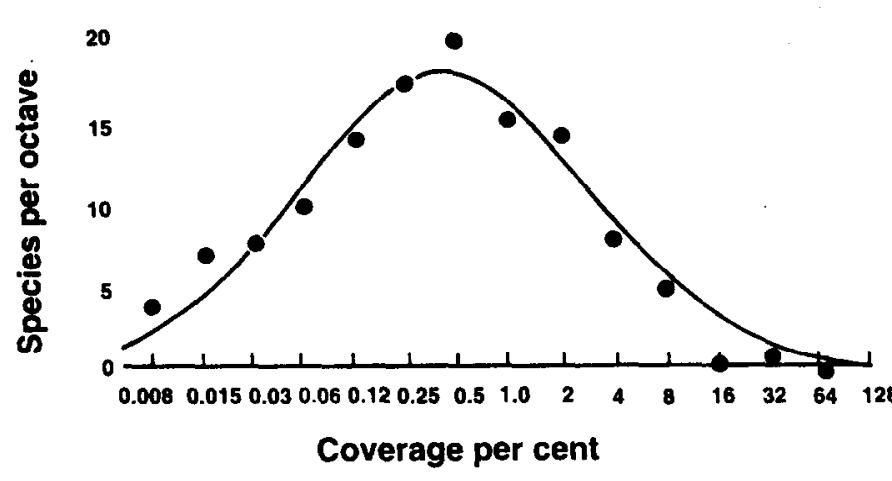

Fig. 3. Log-normal statistical distribution of Sonoran Desert plants (Whittaker 1965). Reprinted with permission of the American Association for the Advancement of Science. Octaves are classes of abundance ordered by doubling of cover values.

aspects should be more common in the future (Cousins 1991).

Wayne and Bazzaz (1991) point out that although indices based merely on species may be useful, species (except microorganisms [Chapin et al. 1992]) are generally unreliable units for quantifying the ecological diversity perceived and utilized by most organisms in communities because they are based on taxonomic, not functional bases (Walker 1992). Limiting our analyses to just species designations greatly under-estimates the complexity of communities, ecosystems, and landscapes. Some species-rich communities may be much less ecologically diverse than species-poor communities. For instance, a community with a lot of similarly sized grasses and forbs would be less structurally and functionally diverse than a community with a single abundant shrub species and fewer grasses and forbs. Wayne and Bazzaz (1991) propose categorizing organisms by genetic, phenetic, gender, developmental state and/or maternal effects to obtain additional insight about how communities are structured and function.

\section{Choice of Method}

There is no such thing as an "objective" index of biodiversity. The numerical values produced are dependent on human choices of the area to be sampled, how often it was sampled, any selection of variable(s) to express presence or dominance and the particular formulae used to synthesize the data (West and Reese 1991). Interpretation and comparison of numbers expressing community biodiversity are difficult. The unaware or unscrupulous can, intentionally or not, "bend" the numbers to favor certain conclusions. Methods should be selected on the basis of the question(s) being asked of the survey, experiment, or monitoring program.

A numerical index may stay the same or nearly so, but a community could change significantly, such as reductions in the abundance of major species. This is because most indices treat all species as equals. Several species could be lost, but if several new species replace them at about the same relative abundance, the index values would remain about the same. One thus needs to compare similarity or dissimilarity as well as diversity. In other words, turnover of taxa and functional groups over time or space needs to be specified. Simply maintaining community diversity as expressed in an index does not ensure maintenance of quality. We have to also be concerned with maintaining the desired species in the desired communities. Choice of benchmarks for comparison is also critical (West 1991a).

\section{Impact of Current Laws and Regulations}

Biodiversity has had such intuitive appeal to the public that their legislators have passed laws despite immaturity of the underlying science (Redford and Sanderson 1992). The 2 major U.S. laws in place that deal with biodiversity on rangelands are the National Forest Management Act of 1976(NFMA) and the Surface Mining Control and Reclamation Act of 1977 (SMCRA). There are, however, numerous other laws, regulations, and executive orders that also require consideration of biodiversity (Kirby 1984, Stockwell 1990).

\section{National Forest Management Act}

The National Forest Management Act requires the U.S. Forest Service to consider natural diversity as a requirement, criterion, and output of good wildland management. Section $6(\mathrm{~h})$ defines diversity as "the distribution and abundance of different plant and animal communities and species within the area covered by a land and resource management plan." Furthermore, the management prescription for national forests "where appropriate and to the extent practicable, will preserve and enhance the diversity of plant and animal communities." Sec. $219.13 \mathrm{~g}$ also calls for maintaining viable populations of native vertebrates. Regulations implementing the act require maintenance of natural diversity on national forest lands and call for environmental monitoring to insure that natural diversity is maintained. The Forest Service is still grappling, however, with ways to meet these goals (McMinn 1991). The Klamath National Forest in northern California is probably the lead Forest Service unit in devising inventory, planning, action, and monitoring procedures to accommodate biodiversity (Williams and Marcot 1991).

\section{Surface Mining Control and Reclamation Act}

The Surface Mining Control and Reclamation Act requires the establishment of a: “...diverse, effective, and permanent vegetation cover...capable of self-regeneration and plant succession at least equal in extent of cover to the natural vegetation of the area..." on all lands after disturbance from surface mining. Of the sundry requirements for revegetation success, the re-establishment of diversity may be the most difficult to satisfy (Laycock 1980, DePuit 1984, Hatton et al. 1986, Hatton and West 1987).

The state regulatory agencies for coal stripmining have not taken a broad view of how to measure diversity. Currently, their focus is on intra-community (alpha) plant diversity only (Krabbenhoft et al. 1991), although inter-community (beta) and landscape (mosaic or gamma) diversity may be equally important in reestablishing wildlife habitat desirability (Laycock 1980, Krabbenhoft et al. 1991). The prevailing choice of an alpha index is the ShannonWiener index, which weights species equally via information theory and thus favors the establishment and persistence of rare species over abundant species. Consequently, it is more difficult to show an improvement in biodiversity and to subsequently obtain bond release than if a probability theory-based index were used. Moreover, the use of information theory-based indices limits habitat quality in terms of wildlife, livestock, and watershed considerations. Some erroneous assumptions about how diversity relates to stability (Peters 1991, Allen and Hoeskstra 1992) lie at the core of these missed opportunities.

\section{Biodiversity and Rangeland Management}

Having reviewed the general problems with defining and applying these principles and measuring biodiversity in special circumstances, let us turn to how these issues relate to all kinds of rangelands.

\section{Concentration on Vertebrates}

The biodiversity issue first gained public attention in the U.S. because of the concern for diminishing prospects for survival of some vertebrates, (the often-called "charismatic fauna" or "flagship" species [Noss 1990]). These organisms were first formally dealt with after passage of the Endangered Species Act in 1973. 
Those species, already having low densities and isolated distributions, are the ones most vulnerable from any type of single influence or cumulative effects. Monitoring of population dynamics of vertebrates and separating natural from human-induced impacts on densities is notoriously difficult (Pechmann et al. 1991). Furthermore, management policies that focus monitoring efforts too high on the food chain run the risk of permanent damage to more basic components (e.g., soils [Sidle and Sharpely 1991]) and functions (Walker 1992) of ecosystems. This is because statistically significant changes in animal populations usually lag behind significant changes in lower trophic levels and the supporting environment.

The Natural Heritage programs in each of the United States and European countries have already identified the rarer vertebrate and vascular plant species and where they are located (Stolzenberg 1992). We can now use care in managing around such taxa. We do not, however, generally have similar information in other parts of the world. We lack similar data for invertebrate animals, nonvascular plants, and microbes, even in Europe, the USA, and other developed countries. Such less noticeable species may even be more important for maintaining ecosystem "health" or affecting ecosystem recovery than the more visible organisms (Perry et al. 1989). Large terrestrial mammals make up only $0.02 \%$ of all North American species (Grumbine 1990), yet they have received the "lion's share" of our attention.

Wide-ranging vertebrates, particularly predators and carrioneaters, have been the most visibly impacted animals on rangelands. I can point to several that are jeopardized by activities ancillary to the management of livestock on rangelands-the grizzly bear, Mexican wolf, black-footed ferret, and California condor. The Mexican wolf now survives only in ex situ (off-site) protection. That is, they have been removed from the wild and are being bred in captivity. The black-footed ferret has been and continues to be captive-bred; captive-bred individuals were recently released on rangelands in Wyoming's Shirley Basin. Two captive-bred condors were released in Southern California in 1992. Reestablishment of the ferret, condor, and Mexican wolf in the wild is questionable. The cost of such programs is enormous and detracts from proactive efforts to keep other species from joining the rare and endangered lists. We can expect the management of the most promising sites for reintroduction of such "emergency room" species to be carefully monitored and controlled to try and save these and other publicly favored species. If you deal with rangeland in such areas, be prepared for these influences on your style of land management.

\section{Causes for Declining Diversity on Rangelands}

\section{Species Level}

While continuous, heavy livestock grazing and trampling can reduce some rare plant species (e.g., the uncharismatic, but taxonomically distinctive Oryctes nevadensis in California [Holsinger and Gottlieb 1991]), especially palatable herbs, indirect effects are probably more significant for animals. For instance, diminishment of the Hawaiian crow and many other species in the tropics is apparently due to clearing of forests to create pastures for cattle (Holden 1992). Changing vegetation structure does indeed influence the variety and abundance of particular native animals. Where livestock grazing has gone on more moderately, without associated mechanical or chemical vegetation manipulations, what is cause and effect is far more questionable. For instance, decline of the masked bobwhite quail is correlated with the expansion of tall shrubs into formerly desert grasslands along the Arizona-Sonora border. The change to greater amounts of shrubs and succulents has, however, been going on for a long time (Van Devender 1990) and how much of this change can be attributed to livestock versus climate and other causes of change is debatable (Bahre 1991). Expect similar debates to develop concerning mountain quail, sage grouse, and sharptail grouse in the Pacific Northwest.
Another herbivore that seems to be declining in the southwestern deserts is the desert tortoise. Although some attempt connecting the decline of this animal to livestock grazing (Berry 1978), livestock use had declined well before tortoise densities slipped and recent studies have shown that it prefers grazing on the introduced annuals (Bostick 1990). It thus seems that other influences such as increased predator densities (e.g., a 15-fold increase in ravens over the past few decades), increased off-road vehicular traffic, diseases, and direct human removal could well be more important than vegetation changes and cattle trampling of animals and dens (Huxtable 1992). Removal of livestock from public rangelands occupied by the desert tortoise is an action that is more politically than scientifically supportable.

Some rare species are favored by ungulate grazing. For instance, the mountain plover nests only in relatively heavily grazed shortgrass steppe (Graul 1973, 1975; Ryder 1980; Leachman and Osmondson 1990). This bird probably evolved with bison influences that only cattle can now replace. Ryder (1980) notes that bird species can be placed into decreaser, increaser, and invader categories as easily as plants. The buttercup, Ranunculus ophioglossifolius, in Great Britain can only be sustained where heavy sheep grazing is maintained (Frost 1981). Sheep grazing was also found to be beneficial to populations of the early spider orchid (Ophrys sphegodes) in England, apparently because maintenance of a short turf reduces interspecific competition (Hutchings 1987). Earlier cattle grazing was leading to declines of this species, apparently because of less close cropping of competitors and mechanical hoof damage. We can thus expect livestock to be used in some instances to actually enhance conservation of species preferring certain successional niches.

Any comprehensive biodiversity program must include threatened and endangered species as a major priority. High priority must also be given to approaches that are more holistic than the piecemeal, crisis efforts into which threatened and endangered species force the scientific and land management communities. Working with individual species ad finitum focuses on symptoms rather than underlying causes.

\section{Community Level}

We have long known that herbivores influence community-level diversity through differentially utilizing or trampling plants variously susceptible to defoliation and other physical damage. For instance, Waser and Price (1981) show how heavy, year-long grazing can diminish the variety of herbs near water and fence corners in the Sonoran Desert. Moderate intensities and periodicities of grazing and trampling usually increase community level diversity of plants by decreasing the ability of community dominants to competitively exclude other species (Quinn and Robinson 1987) and by creating physical gaps and freeing resources such as light, moisture, and nutrients (Archer and Smeins 1991). Collins and Barber (1985) evaluated the effects of fire, grazing, bison wallows, and prairie dog towns on plant diversity in a mixed-grass prairie in southwestern Oklahoma. Plant species diversity was highest on grazed wallows without fire. Lightly to moderately grazed areas had somewhat less diversity. The lowest diversity was associated with recently burned, ungrazed sites. Bonham and Lerwick (1976) found that plant community richness was greater on prairie dog towns than for adjacent uncolonized areas within shortgrass prairie of northeastern Colorado. Similar trends were noted elsewhere by Hansen and Gold (1977), Archer et al. (1987), and Coppock et al. (1983).

The effects of grazing on plant community-level diversity depends on grazing intensity, evolutionary history of the site, and climatic regimes (Milchunas et al. 1988). In semiarid grasslands with a strong evolutionary history of grazing, herbivory appears to have a relatively small effect on community composition (Fig. 4; 


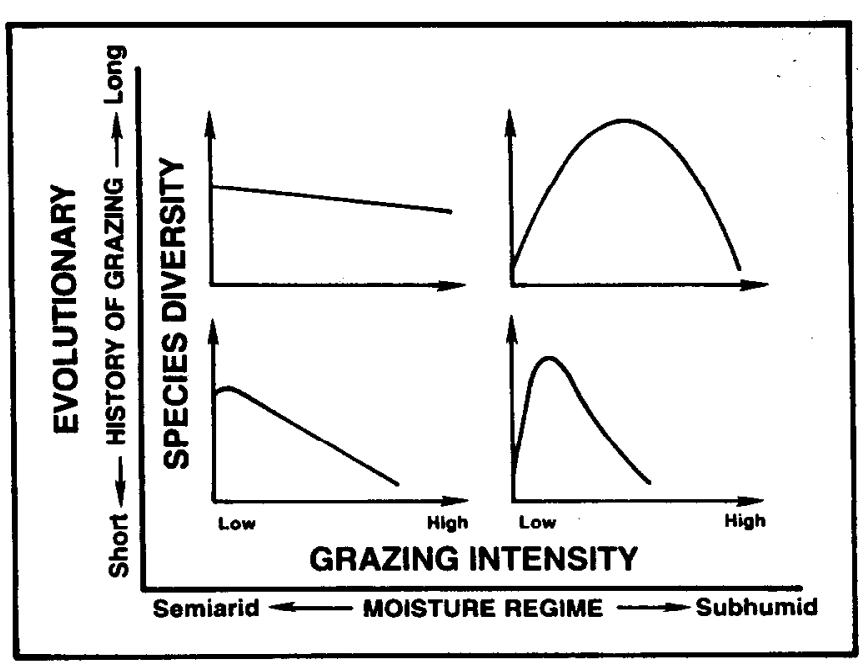

Fig. 4. Hypothesized reiationships between relative plant species diversity in grasslands in relation to grazing intensity along gradients of moisture and evolutionary history of grazing (Milchunas et al. 1988). Published with permission of the University of Chicago Press.

e.g., the shortgrass plains of the U.S. and Canada). In contrast, climatically similar grasslands with a shorter evolutionary history of large mammal grazing lose diversity at much lower grazing intensities; e.g., Argentine pampas. Under wetter conditions, moderate grazing usually enhances diversity regardless of differing evolutionary history (Fig. 4). For instance, Ellenberg (1988) proposes that livestock grazing will have to be increased to enhance diversity of herbaceous plant communities of central Europe which are experiencing dramatic nitrogen and sulfur enrichment due to air pollution which drives dominance by a few species thriving under high nutrient inputs.

Another demonstration of how livestock grazing can have a role in enhancing community biodiversity comes from Israel where Naveh and Whittaker (1979) showed that greater plant diversity for several rangeland sites in Israel existed on moderately grazed areas rather than either ungrazed or heavily grazed areas (Fig. 5). Mueggler (1984) demonstrated similar patterns for sagebrush

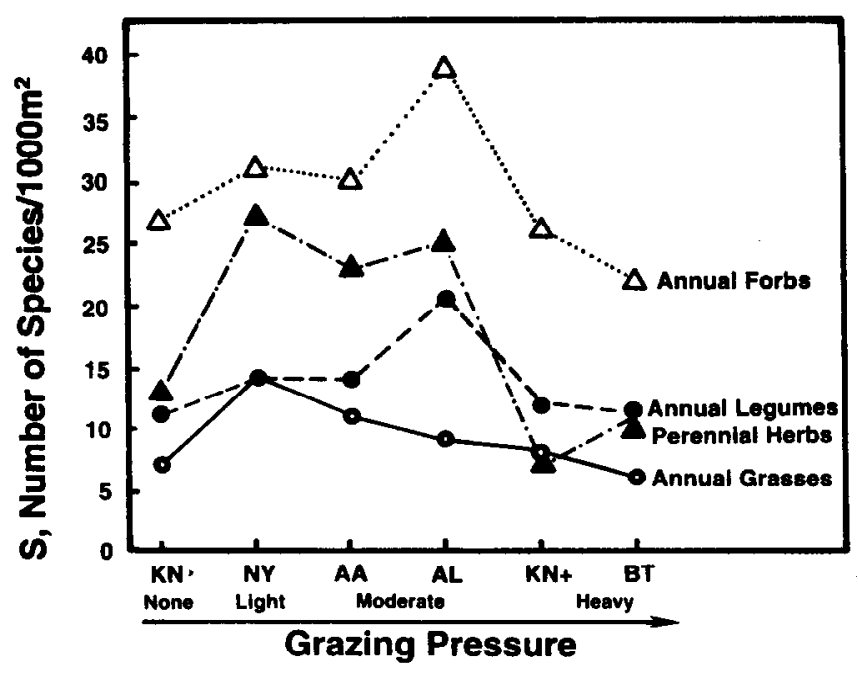

Fig. 5. Species richness in major herb groups of open woodlands and shrublands in relation to grazing pressure (Naveh and Whittaker 1979). Reprinted with permission of Kluwer Academic Publishers. steppe and aspen rangelands in Montana. Ungulate grazing is an important process in many rangeland ecosystems. If grazing is excluded, biodiversity may increase in the short term, but may decline long-term because the system itself changes and in the future may be less able to withstand other disturbances such as drought and fire (Walker 1989).

\section{Ecosystem Level}

Whether losses of species lead to community-level reorganizations which are functionally important, requires careful, long-term observation of ecosystems (Holdgate 1991, Walker 1992, Solbrig 1992). For instance, although loss of the American chestnut and the passenger pigeon from the eastern deciduous forest region of the U.S. led to some short-term economic impacts for particular people who harvested them for fiber and food, other species filled in the space and used resources these species once tied up (Johnson and Mayeaux 1992). No undesirable long-term changes in total productivity and watershed protection were noticed. Resilience at the community and ecosystem levels was thus high for these particular losses because of apparent structural and functional redundancy.

The functional consequences of species-level biodiversity at the ecosystem level is still being debated (Chapin et al. 1992, Walker 1992). Most ecosystems exhibit species richness higher than that required for efficient biogeochemical and trophic functions (di Castri 1991). Functional groupings have been proposed as a means of aggregating species having similar effects on ecosystem processes (Walker 1992). Because we can never determine how each species affects all ecosystem functions, such groupings may be a practical necessity. Where there is more than 1 species per functional group, it implies that species within a functional group may be equivalent or redundant in their impacts on ecosystem processes and that ecosystems could function equally well with fewer species.

Theories of community-ecosystem interaction range from the "rivet" hypothesis (Ehrlich and Ehrlich 1981), where each species plays an incrementally important role (like rivets in an airplane), to that of communities composed of a few functional groups, each with several ecologically equivalent species such that some may be lost with little effect on ecosystem processes (the full redundancy hypothesis). The truth probably lies somewhere between these extremes (Walker 1992).

Redundancy can be thought of as "insurance" or "backup" because each species can tolerate only a limited range of climatic and biotic conditions. If there are several species in each structural and functional group, those structural and functional features are more likely to persist under global environmental change. We know, for instance, that loss of major trees or shrubs in some rangeland systems can have cascading effects through food chains, energy flow, water, and nutrient cycles. For instance, removal of trees and shrubs from subtropical rangelands results in a reorganization of native bird (Johnson et al. 1980) and mammal communities, micro climates (Belsky et al. 1989), water budgets (Blackburn 1983, Carlson et al. 1990), and the nitrogen cycle (West 1991b). Leaving a patchwork of trees and openings can actually optimize the mix of cattle and wild ungulates, apparently because of enhancement of browse production and edge (Fulbright and Beasom 1987). Whether those changes are desirable or not depends on who is paying the bills and benefiting from the consequences.

\section{Landscapes}

If paddocks or allotments are large enough, and water and salt are available only at certain points, then gradients of disturbance and consequent successional status should be available across the landscape (Andrew 1988, Laycock 1992). Thus, it is conceivable that total diversity across a landscape could be enhanced by some 
patterns of livestock use. Furthermore, some treatments such as prescribed burning and chaining can actually enhance community and landscape diversity in some rangeland settings (Mueggler 1984).

\section{Regions}

A major threat to sustaining biodiversity at all lower hierarchial levels is reduced size of contiguous habitats. Habitat fragmentation is regarded by many as a major problem influencing land management (Burton et al. 1992). Blockstein (1990) maintains that preservation of multiple examples of all natural communities occurring in the U.S. should be a national goal. The assumption is that maintaining communities or ecosystems automatically ensures perpetuation of a large component of species. The validity of this approach depends on selection and application of community and ecosystem classifications. Most classification systems are based on a small number of dominant species; the mere occurrence of those species at any age or state of community development does not ensure that all potential component species and functions exist (McMinn 1991).

\section{Potential Solutions}

Rather than wait for others to impose their will, I strongly suggest that academia, the professional societies, and the resource management and advisory agencies take a proactive stance and begin making their own suggestions of what diversity is, how it should be inventoried, monitored, and incorporated into management plans and actions.

\section{Genetic Resources}

With the potential of transgenic (gene splicing between taxonomically disparate organisms) manipulation now proven, any species could be genetically useful to mankind in the future. Furthermore, particular genetic populations could become more valuable than the common ones we have used thus far. For instance, ecotypes of grasses with unusual tolerance to heavy metals have become valuable in revegetating areas disturbed by mining (Wainwright and Woolhouse 1975). Other populations are naturally selected by grazing, fire, herbicides, etc. Range practitioners can use such material to advantage in rehabilitation activities. Until details of genetic variation of many more species are available, it behooves us to protect isolated populations.

\section{Species Protection}

It is rapidly becoming evident that not all species now found on earth will remain during the 21 st century (Ehrlich and Wilson 1991, Holdgate 1991). Furthermore, it has become evident that passive management or attempts at preservation do not protect all species. For instance, Newmark (1987) found that between 0 and $43 \%$ of the original (pre-establishment) large mammal fauna have been lost from our large western national parks in the U.S., the variation depending largely on their size and time since establishment. Furthermore, broadening "preservation" attempts will eventually curtail economic growth. We will thus be forced to decide which aspects of biodiversity are most important. Adherence to policies that place equal emphasis on every species is both ecologically unsound and tactically unachievable (Walker 1992).

\section{Communities, Ecosystems, Landscapes}

With the creation of national plans for further wildlife reserves and corridors (Scott et al. 1987), the greater ecosystem concept (Grumbine 1990), and regional assessment of environmental health through the Environmental Protection Agency's Environmental Monitoring and Assessment Program (EMAP) (Hunsaker and Carpenter 1990), even private landholders will probably see further governmental control of how their lands can be managed, in the name of maintaining or enhancing biodiversity. The public is beginning to realize that not all biota are preserved or protected in existing parks, preserves, and refuges (Pimentel et al. 1992). Furthermore, buffers of surrounding land with less heavy use act as corridors of seminatural environments allowing movements of organisms between the parks and preserves, particularly under climatic change scenarios (Peters and Darling 1985). Thus, the importance of other federal, state, and private wildland is being recognized for conservation biology efforts (Brussard 1991).

While most U.S. rangeland surviving until the twentieth century has been marginal for agricultural, urban, and industrial development and consequently less fragmented than ecosystems in wetter parts of the country, even low levels of fragmentation may result in ill-functioning communities (Hanson and Angelstam 1991). We must expect greater efforts to protect declining and under represented ecosystem types (e.g., tall grass prairie, California steppe) in national preserve systems. There will also be increasing attempts to restore missing species and community types (e.g., blackland prairie, longleaf pine-wire grass).

It should be recognized that most of the ideas being pushed by conservation biologists are based on the theory of island biogeography. Not all accept that such theory is applicable to mainlands (Mann 1991). Some continental species can escape into bordering areas once their prime habitat is removed (Boeklen and Gotelli 1984, and Dunn and Loehle 1988). The vast majority of workers in conservation biology have been trained in a species orientation. Accordingly, they have been slow in realizing that the best way to minimize species losses is to maintain ecosystem integrity.

I favor prioritization of maintenance of soil profiles and ecosystem functions as the most important aspects of sustainability (West 1991b). Without these features, overall potentials for all biota are seriously diminished. Furthermore, holding the soils on upland sites and out of aquatic environments seems very important to maintain options for future generations. Global warming may displace temperature zones in middle latitudes of 4 to $6^{\circ}$ northward or 460 to $1,100 \mathrm{~m}$ upslope over the next 100 years (Nielsen et al. 1989). Thus, we do not know where our farmlands will have to be in the future. If the tools of the Green Revolution lose their edge, more marginal arable land will have to be brought into production (Moffat 1992). The world's food supply will have to be doubled by 2010 in order to feed the 90 million more people per year being born. Soils spread across a landscape are better insurance than only rocks on hillsides and deep sediments in depressions.

\section{Research Needs}

Either active (multiple use) or passive management (preservation) of an ecosystem results in adjustments in the population densities of all species and inevitably leads to a shift in relative abundances of co-existing species (community composition). All species are not created ecologically equal. Some are "drivers" and some are "passengers" (Walker 1992). The extent of change will largely depend on the tightness of coupling of the major species to others in the food web (Pimm 1991).

Species whose direct or indirect effects on the survival of other species or on ecosystem function are disproportionately large in relation to their abundance are called "keystone" species (Westman 1990). By definition, there is no redundance in the critical function of a keystone species. For instance, Brown and Heske (1990), in an experimental study at the Chihuahuan-Sonoran Desert ecotone in Arizona, found that without kangaroo rats (Dipodymys spp.) a shrub steppe quickly changed to grassland. The digging of these rodents apparently favors establishment of shrub seedlings. Without them, grass competitively squeezes out shrubs. Despite the importance of keystone species to management, knowledge of them is scant, another deficiency we could begin to correct.

Policies calling for removal of all exotic, alien, or introduced species appear to rest on the old notion of a totally interdependent 
community in which any change in the abundance of any species is a threat to the entire community (the "rivet" hypothesis). However, wildland communities receive continuous new arrivals, yet the adjustments usually do not result in a net loss of species. In fact, plant species richness of the California annual grasslands is probably much higher today than it was prior to coming of European man (Johnson and Mayeaux 1992). Most communities do not consist of highly co-evolved species pairs, but exhibit some substi-: tutability by species within groups (Westman 1990). This is not to deny mutualism and the existence of keystone or critical link species, but rather to acknowledge that not all species play those roles. We need to differentiate between the exotics to worry about and those that are of less worry, based on what they do.

Critical link species are those that play a vital role in ecosystem function, regardless of their biomass, place in a food web, or possible role as a keystone species (Westman 1990). An example of a group of critical link species on rangelands is mychorrhizal fungi. These organisms exchange carbon fixed by green plants for enhanced uptake of phosphorus. Their absence may severely inhibit recovery of about $90 \%$ of the green plants that depend on them. For instance, Wicklow-Howard (1989) has shown that repeated fires promoted by cheatgrass in former sagebrush steppe in the Intermountain West can lead to extinction of mycorrhizae over vast areas and impede reestablishment of shrubs and perennial grasses. Identifying who these critical link species are and finding out whether substitutable species exist is important in setting policy and acting on it. We thus need to get on with the task of identifying critical link species for all kinds of rangelands.

The concepts of minimal and configurational structure (Pickett et al. 1989) are also worth considering. Species composition (configurational structure) within functional groups (minimal structure) may vary widely without collapse of biotic communities or ecoystems. Stennhauser (1991) has recently demonstrated how qualitatively defining stability as the maintenance of minimal structure is a practical way to approach assessment of ecosystem change.

If you agree with Walker $(1989,1992)$, and me, that it is more important to preserve processes than all organisms when functional redundancy can be demonstrated, we also need to discover guild or modular structure. Although Hawkins and MacMahon (1989) and Simberloff and Dayan (1991) have outlined the difficulties of tightly defining such organizational units, the existence of groups of functionally related species within communities having stronger interactions with each other than with the larger food web is undeniable and of great importance for land management (Westman 1990). Grabherr (1989) gives us an example of how we could proceed to identify keystone species, modules, guilds, or functional groups on rangelands.

If sustainable development is to be realized, we need to find ways that natural resources can be both used and maintained. Finding balancing points would be easier if we better understood the role species play in ecosystem functioning. If we can come to identify functional groups, minimal structure, modules, guilds, keystone species, critical link species, and exotics to be worried or not worried about, the older, overly simplistic, species-only notions of biodiversity will be replaced and we will gain a larger role in setting policies on use of rangelands.

\section{Recommendations}

Unfortunately, policy makers have quickly turned what were academic working concepts about biodiversity into packaging buzzwords to fund politically popular programs. The evolving understanding of biodiversity being built by researchers was thus prematurely uncoupled from strong science (Redford and Sanderson 1991). We have land managers trying to implement actions based on fuzzy definitions, loosely worded objectives and inadequate methods of measurement and monitoring because a concerned and impatient public is breathing down their necks.

We have barely begun the tasks of quantifying biodiversity of rangelands and planning management to accommodate these values. Biodiversity is now being viewed from many new perspectives. These expanding views are driving needs for further inventories and monitoring efforts and research beyond the livestock grazing focus the range profession has stressed in the past.

Livestock grazing of any kind does not automatically reduce biodiversity. There are numerous examples of livestock use enhancing retention of some rare species, richness, and equitability of species diversities in communities and over landscapes. Although grazing is an important activity influencing ecosystem structure and function, other tendencies such as global climatic changes and biological invasions may soon overwhelm the influences of livestock in changing the biosphere.

Since it will be tactically impossible to save all species and not all species are equally valuable in maintenance of essential ecosystem states and functions, we should begin a concerted effort to identify which organisms are most important (e.g., keystone and critical link species) and focus our attention to protecting them and the modules, guilds, and functional groups in which they occur. Similarly, not all invading species are equal threats.

Passive, solely protective management of a small fraction of a countryside will not automatically result in a return to earlier conditions there, such as might have existed before the Ages of Discovery and Industrialization, and preservation of a major fraction of the species, genotypes, communities, or ecosystems. Mankind now dominates, either directly or indirectly, every part of the globe. Most biodiversity exists in human-managed areas (Pimentel et al. 1992). The inertia of changes we have already set in motion is too powerful to deny. The only rational response is for us to now recognize and understand these inevitable changes and ameliorate them where possible. We must learn to use lands in a sustainable way such that most biodiversity is also retained (Olsson et al. 1991). The basic guideline should be to prevent the loss of the inherent capacity of the land to produce and so maintain mankind's options for the future.

\section{Literature Cited}

Allen, T.F.H., and T.W. Hoeskstra. 1992. Toward a unified ecology. Columbia Univ. Press, N.Y.

Andrew, M.H. 1988. Grazing impact in relation to livestock water points. Trends Res. Ecol. Evol. 3:336-339.

Anon. 1991a. Threats to biodiversity in the United States. U.S. Environ. Protection Agency, Washington, D.C.

Anon. 1991b. Biological diversity on Federal Lands: A report of a Keystone policy dialogue. Keystone Center, Keystone, Colo.

Archer, S.A., and F.M. Smeins. 1991. Ecosystem-level processes. p. 109-139. In: R.K. Heitschmidt and J.W. Stuth (eds.) Grazing management: An ecological perspective. Timber Press, Portland, Ore.

Archer, S., M.G. Garrett, and J.K. Detling. 1987. Rates of vegetation change associated with prairie dog (Cynomys ludoviciana) grazing in North American mixed-grass prairie. Vegetatio 72:159-166.

Bahre, C.J. 1991. A legacy of change: Historic human impact on vegetation in southern Arizona. Univ. Arizona Press, Tucson.

Belsky, A.J., R.G. Amundson, J.M. Duxberry, S.J. Richa, A.R. Ali, and S.M.Mwonga. 1989. The effects of trees on their physical, chemical, and biological environments in a semi-arid savanna in Kenya. J. Appl. Ecol. 26: $1005-1024$.

Berry, K.H. 1978. Livestock grazing and the desert tortoise. Trans. North American Wildlife and Natural Resources Conf. 43:505-519.

Blackburn, W.H. 1983. Influence of brush control on hydrologic characteristics of range watersheds. p. 73-88. In: K.C. McDaniel (ed.) Proc. Brush Manage. Symp. Texas Tech Press, Lubbock.

Blockstein, D.C. 1990. Toward a federal plan for biological diversity. J. Forest. 88:15-19. 
Boeklen, W.J., and N.J. Gotelli. 1984. Island biogeographic theory and conservation practice; species-area or specious area relationships? Biol Conserv. 29:63-80.

Bonham, C.D., and A. Lerwick. 1976. Vegetation changes induced by prairie dogs on shortgrass range. J. Range Manage. 29:221-225.

Bostick, V. 1990. The desert tortoise in relation to cattle grazing. Rangelands. 12:149-151.

Brown, J.H., and E.J. Heske. 1990. Control of a desert-grassland transition by a keystone rodent guild. Science 250:1705-1707.

Brussard, P.F. 1991. The role of ecology in biological conservation. Ecol. Appl. 1:6-12.

Burton, P.J., A.C. Balesky, L.P. Coward, S.G. Cumming, and D.D. Kneeshaw. 1992. The value of managing for biodiversity. Forest. Chronicle 68:225-237.

Carlson, D.H., T.L. Thurow, R.W. Knight, and R.K. Heitschmidt. 1990. Effect of honey mesquite on the water balance of Texas Rolling Plains rangeland. J. Range Manage. 43:491-496.

Chapin, F.S. III, E-D Schulze, and H.A. Mooney. 1992. Biodiversity and ecosystem processes. Trends Res. Ecol. Evol. 7:107-108.

Christensen, N.L., and R.K. Peet. 1984. Measures of natural diversity. p. 43-538. In: J.L. Cooley and J.H. Cooley (eds.) Natural diversity in forest ecosystems. Proc. Workshop. Univ. Georgia, Athens.

Cody, M.L. 1989. Growth form diversity and community structure in desert plants. J. Arid. Environ. 17:199-209.

Collins, S.L., and S.C. Barber. 1985. Effects of disturbance on diversity in mixed-grass prairie. Vegetatio 64:87-94.

Coppock, D.L., J.K. Detling, J.E. Ellis, and M.I. Dyer. 1983. Plantherbivore interactions in a North American mixed grass prairie. I. Effect of blacktailed prairie dogs on intra-seasonal aboveground plant biomass, nutrient dynamics and plant species diversity. Oecologia 56:1-9.

Cousins, S.H. 1991. Species diversity measurement: choosing the right index. Trends Research Ecol. Evol. 6:190-192.

DePuit, E.J. 1984. Potential topsoiling strategies for enhancement of vegetation diversity on mined lands. In: Third Bien. Symp. on Surface Coal Mine Reclamation on the Great Plains, Billings, Mont.

diCastri, F. 1991. Ecosystem evolution and global change. p. 189-218. In O.T. Solbrig and G. Nicolis (eds). Perspectives in biological complexity. Int. Union Biol. Sci., Paris, France.

Dunn, C.P., and C. Loehle. 1988. Species-area parameter estimation testing the null model of lack of relationship. J. Biogeogr. 15:721-728.

Ehrlich, P.R., and A.H. Ehrlich. 1981. Extinction: The causes and consequences of the disppearance of species. Random House, N.Y.

Ehrlich, P.R., and E.O. Wilson. 1991. Biodiversity studies: Science and policy. Science 253:758-762.

Ellenberg, H. 1988. Floristic changes due to nitrogen deposition in central Europe. In: J. Nilsson and P. Grennfelt (eds.) Critical loads for sulfu and nitrogen. Nordic Council of Ministers.

Frost, L.C. 1981. The study of Ranunculus ophioglossifolius and its successful conservation in the Badgeworth Reserve, Gloustershire. p. 481-489. In: H. Synge (ed.) Biological aspects of rare plant conservation. John Wiley and Sons, N.Y.

Fulbright, T.E., and S.L. Beasom. 1987. Long-term effects of mechanica shrub treatment on white-tailed deer browse. Wildl. Soc. Bull. 15:560-564.

Gomez-Pompa, A., and A. Kaus. 1992. Taming the wilderness myth BioScience 42:271-279.

Grabherr, R. 1989. On community structure in high alpine grasslands. Vegetatio 83:223-227.

Graul, W.D. 1973. Adaptive aspects of the mountain plover social system. Living Bird 12:69-94.

Graul, W.D. 1975. Breeding biology of the mountain plover. Wilson Bull 87:6-31

Grumbine, E. 1990. Protecting biological diversity through the greater ecosystem concept. Natural Areas J. 10:114-120.

Hansson, L., and P. Angelstam. 1991. Landscape ecology as a theoretical basis for nature conservation. Landscape Ecol. 5:199-201.

Hansen, R.M., and I.K. Gold. 1977. Blacktailed prairie dogs, desert cottontails and cattle trophic relations on shortgrass prairie. J. Range Manage. $30: 210-214$

Hatton, T.J., S.L. Durham, and N.E. West. 1986. Estimating components of plant community diversity on mined lands. p. 102-105. In: D. Williams and S.E. Fisher (eds.) Proc. Annu. Meet. Amer. Soc. for Surface Mining and Reclam. Denver, Colo.

Hatton, T.J., and N.E. West. 1987. Early seral trends in plant communities on a surface coal mine in southwestern Wyoming. Vegetatio 73:21-29.

Hawkins, C.H., and J.A. MacMahon. 1989. Guilds: the multiple meanings of a concept. Annu. Rev. Entomol. 34:423-451.
Hill, M.O. 1973. Diversity and evenness: a unifying notation and its consequences. Ecology 54:427-432.

Holden, C. 1992. A call for action on the Alala. Science 256:1136.

Holdgate, M.W. 1991. The environment of tomorrow. Environment $33: 15-20,40-42$.

Holsinger, K.E., and L.E. Gottlieb. 1991. Conservation of rare and endangered plants: Principles and prospects. p. 195-208. In: D.A. Folk and K.E. Holsinger (eds.) Genetics and conservation of rare plants. Oxford Univ. Press, N.Y.

Hoover, S.R., and A.J. Parker. 1991. Spatial components of biotic diversity in landscapes of Georgia. Landscape Ecol. 5:125-136.

Howarth, G. 1983. Classical biocontrol: pancea or pandora's box. Proc. Hawaiian Ent. Soc. 24:239-244.

Hunsaker, C.T., and D.E. Carpenter (eds.) 1990. Environmental monitoring and assessment program: Ecological indicators. Environ. Prot. Agency/600/3-90/060. Office of Research and Development, Research Triangle Park, N.C.

Hutchings, M.J. 1987. The population biology of the early spider orchid. Ophyrs spregodes Mill. I.A. demographic study from 1975-1984. J. Ecol. 75:711-727

Huxtable, N, 1992. The desert tortoise. Rangelands 14:33-34.

Johnson, R.R., L.T.Haight, M.M. Riffey, and J.M. Simpson. 1980. Brushland/steppe land communities. p. 91-112. In: Management of Western forests and grasslands for nongame birds. USDA, Forest Serv., Intermount. Forest and Range Exp. Sta., Ogden, Ut. Gen. Tech. Rep. INT-86.

Johnson, H.B., and H.S. Mayeaux. 1992. A view on species additions and deletions and the balance of nature. J. Range Manage. 45:322-333.

Kirby, P.E. 1984. Natural diversity requirements in environmental legislation affecting national forest planning (except the National Forest Management Act). p. 11-20. In: J.L. Cooley and J.H. Cooley (eds.). Natural diversity in forest ecosystems. Proc. Workshop, Univ. Georgia, Athens.

Krabbenhoft, K., D. Kirby, M. Biondini, and D. Nilson. 1991. Plant diversity patterns on North Dakota mined lands. p. 555-561. In: W.R. Oaks and J. Bowden (eds.) Proc. Nat. Meeting, Amer. Soc. Surface Mining and Reclam., Princeton, W.V.

Laycock, W.A. 1980. What is successful reclamation? A look at the concepts of adaptability, productivity, cover, and diversity of seeded species. Proc. Northwest Colorado Land Reclam. Seminar II. Steamboat Springs, Colo.

Laycock, W.A. 1992. Implications of grazing vs no grazing on today's rangelands. Proc. Symp. on Ecological Implications of Livestock Herbivory in the West. Soc. Range Manage., Denver. (In Press).

Leachman, B., and B. Osmundson, 1990. Status of the mountain plower: A literature review. U.S. Fish and Wildlife Serv., Golden, Colo.

Lewis, C.E., B.F. Swindel, and G.W. Tanner. 1988. Species diversity and diversity profiles: Concept, measurement, and application to timber and range management. J. Range Manage. 41:466-469.

Ludwig, J.A., and J.F. Reynolds. 1988. Statistical ecology: A primer on methods and computing. John Wiley and Sons, N.Y.

Magurran, A.E. 1988. Ecological diversity and its measurement. Princeton Univ. Press, Princeton, N.J.

Mann, C.C. 1991. Extinction: Are ecologists crying wolf: Science 253:736-78.

McMinn, James W. 1991. Biological diversity research: an analysis. Gen. Tech. Rep. SE-71. Asheville, N.C. USDA, Forest Serv., Southeastern Forest Exp. Sta.

McNeely, J.A., K.R. Miller, W.V. Reid, R.A. Mittermeier, and T.B. Werner. 1989. Conserving the World's Biological Diversity. Int. Union for Conserv, of Nature, Gland, Switzerland.

Meuggler, W.F. 1984. Diversity of western rangelands. p. 211-217. In. J.L. Cooley and J.H. Cooley (eds.). Natural Diveristy in Forest Ecosystems. Proc. Workshop, Univ. Georgia, Athens, Ga.

Milchunas, D.G., O.E. Sala, and W.K. Lauenroth. 1988. A generalized model of the effects of grazing by large herbivores on grassland community structure. Amer. Natur. 132:87-106.

Moffat, A.S. 1992. Does global change threaten the world food supply? Science 256:1140-1141

Naveh, Z., and R.H. Whittaker. 1979. Structural and floristic diversity of shrublands and woodlands in northern Israel and other Mediterranean Areas. Vegetatio 41:171-190.

Nielsen, R.P., G.A. King, R.L. DeVelice, J. Lenihan, D. Marks, J. Dolph, B. Campbell, and G. Glick. 1989. Sensitivity of ecological landscapes and regions to global climate change. U.S. Environ. Prot. Agency, EPA/ 600/3-89/73. Corvallis, Ore.

Newmark, W.D. 1987. A landbridge perspective on mammalian extinctions in western North American parks. Nature 325:430-432. 
Noss, R.F. 1990. Indicators for monitoring biodiversity: A hierarchial approach. Conserv. Biol. 4:355-364.

Olsson, G.A. L-E. Liljelund, and L. Hedlund. 1991. A strategy for the conservation of biodiversity. Ambio 20:269-270.

Palmer, M.W. 1990. The estimation of species richness by extrapolation. Ecology 71:1195-1198.

Pechmann, J.K., D.E. Scott, R.D. Semlitsch, J.P. Caldwell, L.J. Velt, and J.W. Gibbons. 1991. Declining amphibian populations: The problem of separating human impacts from natural fluctuations. Science 253:892895.

Peet, R.K. 1974. The measurement of species diversity. Annu. Rev. Ecol. System. 5:285-307.

Perry, D.A., M.P. Amaranthus, J.G. Borchers, and R.E. Brainerd, 1989. Bootstrapping in ecosystems. BioScience 39:230-237.

Peters, R.H. 1991. A critique for ecology. Cambridge Univ. Press.

Peters, R.L., and J.D.S. Darling. 1985. The greenhouse effect and nature reserves. BioScience 35:707-717.

Pickett, S.T.A., J. Kolasa, J. Armesto, and S. Collins. 1989. The ecological concept of disturbance and its expression at various hierarchial levels. Oikos 54:129-136.

Pickup, G. 1989. Remote sensing of landscape processes. p. 221-247. In: R.J. Hobbs and H.A. Mooney (eds.). Remote sensing of biosphere functioning. Springer-Verlag, N.Y.

Pielou, E.C. 1966. The measurement of diversity in different types of biological collections. J. Theoret. Biol. 13:131-144.

Pimentel, D., U. Stachow, D.A. Takas, H.W. Brubaker, A.R. Dumas, J.J. Meaney, J.A.S. O'Neil, D.E. Onsi, and D.B. Corzilius. 1992. Conserving biological diversity in agricultural/forestry systems. BioScience 42:354-362.

Pimm, S.L., and J.L. Gittleman. 1992. Biological diversity: Where is it? Science 255-940.

Pimm, S.L. 1991. The balance of Nature? Ecological issues in the conservation of species and communities. Univ. Chicago Press, Chicago.

Quinn, J.F., and G.R. Robinson. 1987. The effects of experimental subdivision on flowering plant diversity in a California annual grassland. J. Ecol. 75:837-856.

Redford, K.H., and S.E. Sanderson. 1992. The brief, barren marriage of biodiversity and sustainability. Bull. Ecol. Soc. Amer. 73:36-39.

Romme, W.H., and D.H. Knight. 1982. Landscape diversity: The concept applied to Yellowstone Park. BioScience 32:644-670.

Routledge, R.D. 1979. Diversity indices: Which ones are admissable? J. Theoret. Biol. 76:503-515.

Routledge, R.D. 1984. Estimating ecological components of diversity. Oikos 42:23-29.

Ryder, R.A. 1980. Effects of grazing on bird habitats. p. 51-66. In: R.M. DeGraff and N.G. Tilghmann (eds.). Management of Western forests and grasslands for nongame birds. U.S. Forest Serv., Gen. Tech. Rep. INT-86. Intermount. Res. Sta., Ogden, Ut.

Salwasser, H. 1991. Diversity: new perspectives for sustaining diversity in U.S. Nation Forest Ecosystems. Conserv. Biol. 5:567-569.

Scott, J.M., B. Csuti, J.D. Jacobi, and J.E. Estes. 1987. Species richness: A geographic approach to protecting future biological diversity. BioS cience 37:782-788.

Scott, J.M., B. Csuti, K. Smith, J.E. Estes and S. Caicco. 1988. Beyond endangered species: an integrated strategy for the preservation of biological diversity. Endangered Species Update. 5:43-48.

Scott, J.M., b. Csuti, J.E. Estes, and H. Anderson. 1989. Status assessment of biodiversity protection. Conserv. Biol. 3:85-87.

Shmida, A., and M.V. Wilson. 1985. Biological determinants of species diversity. J. Biogeogr. 12:1-20.

Simberloff, D., and T. Dayan. 1991. The guild concept and the structure of ecological communities. Ann. Rev. Ecol. System. 22.
Sidle, R.C., and A.N. Sharpely. 1991. Cumulative effects of land management on soil and water resources: an overview. J. Environ. Qual. 20:1-3. Simpson, E.H. 1949. Measurement of diversity. Nature 163:688.

Solbrig, O.T. 1992. The IUBS-UNESCO Program for research in biodiversity. Ecol. Appl. 2:131-138.

Stennhauser, E.B. 1991. The concept of stability in connection with the gallery forests of the Chaco region. Vegetatio 94:1-13.

Stockwell, S.S. 1990. U.S. national policies related to maintaining biological diversity in forests. p. 291-295. In: M.L. Hunter Jr. Wildlife, Forests and Forestry. Prentice-Hall, Englewood Cliffs, N.J.

Stolzenburg, W. 1992. The Heritage Network: detectives of diversity. Nature Conservancy. Jan. Feb., p. 23-27.

Turner, S.J., R.V. O Nell, W. Conley, M.R. Conley, and H.C. Humphries. 1990. Pattern and scale: Statistics for landscape ecology. p. 17-49. In: M.G. Turner and R.H. Gardner (eds.). Quantitative methods in landscape ecology Ecol. Studies 82, Springer-Verlag, N.Y.

Van Devender, T.R. 1990. Late quaternary vegetation and climate of the Sonoran Desert, United States and Mexico. p. 134-165. In: J.L. Betancourt, T.R. Van Devender and P.S. Martin (eds.) Packrat middens: The last 40,000 years of biotic change. Univ. Arizona Press, Tucson.

Wainwright, S.J., and H.W. Woolhouse. 1975. Physiological mechanisms of heavy metal tolerance in plants. p. 231-257. In: M.J. Chadwick and G.T. Goodman (eds.). The ecology of resource degradation and renewal. Blackwell Sci. Publ., Oxford.

Walker, B. 1989. Diversity and stability in ecosystem conservation. p. 121-130. In: D. Western and M. Pearl (eds.). Conservation for the Twenty-first Century. Oxford Univ. Press, N.Y.

Walker, B.H. 1992. Biological and ecological redundancy. Conserv. Biol. 6:18-23.

Waser, N.M., and M.V. Price. 1981. Effects of grazing on diversity of annual plants in the Sonoran Desert. Oecologia 50:407-411.

Wayne, P.M., and F.A. Bazzaz. 1991. Assessing diversity in plant communities: The importance of within-species variation. Trends in Ecol. Evol. 6:400-401.

West, N.E. 1991a. Benchmarks for rangeland management and environmental quality. p. 30-44. In: L.F. James, J.O. Evans, M.H. Ralphs, and R.D. Child (eds.) Noxious range weeds. Westview Press, Boulder, Colo.

West, N.E. 1991b. Nutrient cycling in soils of semiarid and arid regions. p. 295-232. In: Skujins (ed.). Semiarid lands and deserts: Soil resource and reclamation. Marcel Dekker, Inc., N.Y.

West, N.E., and G.A. Reese. 1991. Comparison of some methods for collecting and analyzing data on aboveground net production and diversity of herbaceous vegetation in a northern Utah sub-alpine context. Vegetatio 96:145-163.

Westman, W.A. 1977. How much are nature's services worth? Science 197:960-964.

Westman, W.A. 1990. Managing for biodiversity. BioScience 40:26-33.

Whittaker, R.H. 1965. Dominance and diversity in land plant communities. Science 147:250-260.

Wicklow-Howard, M. 1989. The occurrence of vesicular-arbuscular mycorrhizae in burned areas on the Snake River Birds of Prey Area, Idaho. Mycotaxon 34:253-257.

Williams, C.B. 1964. Patterns in the balance of Nature and related problems in quantitative ecology. Academic Press, N.Y.

Williams, B.L., and B.G. Marcot. 1991. Use of biodiversity indicators for analyzing and managing forest landscapes. Trans. N.A. Wildl. \& Nat. Res. Conf. 56:613-627.

Yorks, T.P., N.E. West, and K.M. Capels. 1992. Vegetation change in desert shrublands of western Utah's Pine Valley, 1933-1989. J. Range Manage. 45:569-578. 